\title{
EPIDEMIOLOGICAL PROFILE OF 39 CASES OF MICROCEPHALY CAUSED BY CONGENITAL INFECTIONS DIAGNOSED IN THE STATE
OF RIO GRANDE DO SUL BETWEEN 2015-2017
}

\author{
Silvani Herber ${ }^{1}$, Anna Pires Terra ${ }^{2,3}$, André Anjos da Silva ${ }^{3,4}$, \\ Maria. Teresa V. Sanseverino 2,5 , Lucas Rosa Fraga ${ }^{6}$, \\ Fernanda Sales Luiz Vianna ${ }^{7,3}$, Ida Vanessa Doederlein Schwartz ${ }^{1,2,8}$, \\ Lavínia Schuler-Faccini ${ }^{2,3,9,8}$, Luciana Friedrich ${ }^{10,11}$
}

Clin Biomed Res. 2019;39(3):200-208

1 Programa de Pós-graduação em Medicina, Universidade Federal do Rio Grande do Sul (UFRGS). Porto Alegre, RS, Brasil.

2 Serviço de Genética Médica, Hospital de Clínicas de Porto Alegre (HCPA). Porto Alegre, RS, Brasil.

3 Serviço de Informação Teratogenética (Siat), Hospital de Clínicas de Porto Alegre (HCPA). Porto Alegre, RS, Brasil.

4 Curso de Medicina, Universidade do Vale de Taquari (Univates). Lajeado, RS, Brasil.

5 Faculdade de Medicina, Pontifícia Universidade Católica do Rio Grande do Sul (PUCRS). Porto Alegre, RS, Brasil.

6 Departamento de Ciências da Saúde, Universidade Federal do Rio Grande do Sul (UFRGS). Porto Alegre, RS, Brasil.

7 Programa de Pós-graduação em Genética e Biologia Molecular, Universidade Federal do Rio Grande do Sul (UFRGS). Porto Alegre, RS, Brasil.

8 Departamento de Genética, Universidade Federal do Rio Grande do Sul (UFRGS). Porto Alegre, RS, Brasil.

9 Instituto Nacional de Ciência e Tecnologia de Genética Médica Populacional (INaGeMP). Porto Alegre, RS, Brasil.

10 Departamento de Pediatria, Universidade Federal do Rio Grande do Sul (UFRGS). Porto Alegre, RS, Brasil.

11 Serviço de Neonatologia, Hospital de Clínicas de Porto Alegre (HCPA), Porto Alegre, RS, Brasil.

Corresponding author: Luciana Friedrich Ifriedrich@hcpa.edu.br Hospital de Clínicas de Porto Alegre (HCPA)

Rua Ramiro Barcelos, 2350

90035-903, Porto Alegre, RS, Brasil.

\section{ABSTRACT}

Introduction: Microcephaly is a clinical finding that can arise from congenital anomalies or emerge after childbirth. Maternal infections acquired during pregnancy can result in characteristic brain damage in the newborn (NB), which may be visible even in the fetal stage. To describe the epidemiological profile of newborns with reported microcephaly and diagnosed with congenital infections in the state of Rio Grande do Sul between 2015 and 2017.

Methods: A cross-sectional study was carried out on data collected from the Public Health Event Registry as well as from medical records. The investigation included serologies for toxoplasmosis and rubella; polymerase chain reaction (PCR) for Zika virus (ZIKV) in the blood and cytomegalovirus in the urine; non-treponemal tests for syphilis; and brain imaging tests.

Results: Of the 257 reported cases of microcephaly, 39 were diagnosed with congenital infections. Severe microcephaly was identified in 13 patients $(33.3 \%)$ and $51.3 \%$ of the cases showed alterations in brain imaging tests. In relation to the diagnosis of congenital infections, three patients $(7.7 \%)$ were diagnosed with ZIKV, nine $(23.1 \%)$ with cytomegalovirus, nine $(23.1 \%)$ with toxoplasmosis, and $18(46.1 \%)$ with congenital syphilis. The three cases of ZIKV showed calcification in brain imaging tests, signs of arthrogryposis, excess occipital skin and irritability, characterizing the typical phenotype of ZIKV infection.

Conclusions: Most cases of congenital infection had severe neurological lesions, particularly the cases of ZIKV, which can cause neurodevelopmental delays and sequelae in these infants throughout early childhood.

Keywords: Microcephaly; congenital infection; zika virus

Microcephaly is a clinical finding that can arise from congenital anomalies or emerge after childbirth, thus having a heterogeneous diagnosis with genetical and environmental etiology ${ }^{1,2}$. It is defined as occipitofrontal circumference, or cephalic perimeter (CP), two standard deviations (SD) below the mean for gestational age, sex and weight, and severe microcephaly consists of $\mathrm{CP}$ less than three SD. This measure indirectly reflects the size of the brain and can predict anomalies in development ${ }^{2,3}$.

Among the main causes that can lead to microcephaly, congenital infections are included as they are important causes of neonatal morbidity and mortality. Maternal infections during pregnancy can result in characteristic brain damage in the newborn (NB), which can be visible even in the fetal stage ${ }^{2}$. In addition to microcephaly, these infections include hydrocephalus, brain calcification, ventriculomegaly, cortical migration anomalies, white matter changes and 
cerebellar hypoplasia ${ }^{1,2}$. The main congenital infections causing microcephaly and/or changes in the central nervous system (CNS) described in the literature are Zika virus (ZIKV), toxoplasmosis, syphilis, rubella and cytomegalovirus (CMV) $)^{1,4,5}$.

In February 2016, the World Health Organization (WHO) acknowledged the alarm issued by the Brazilian Ministry of Health on ZIKV infection and its possible association with cases of microcephaly, declaring a public health emergency of international concern. The incidence of ZIKV infection in the general population showed higher rates in northeastern Brazil $^{6}$. In the state of Rio Grande do Sul, the virus only became endemic in April 2016, which coincided with the beginning of winter ${ }^{3}$. However, due to the epidemic that occurred in 2015-2016, microcephaly notification became mandatory in Brazil ${ }^{6}$. Thus, the objective of this study was to describe congenital infections in NBs with microcephaly reported from December 2015 to the end of 2017 in the state of Rio Grande do Sul.

\section{METHODS}

A cross-sectional, descriptive study was conducted with samples collected from 257 NBs with microcephaly reported to the Public Health Event Registry (RESP) in the state of Rio Grande do Sul between December 1 , 2015 and December 31, 2017.

The criteria for RESP reporting, in the first three months of the study, were defined as CP at birth (measured between 24 hours up to 7 days of life) less than 32 centimeters for all NBs ${ }^{7}$. After that, microcephaly was defined for 2 months as CP at birth less than $31,9 \mathrm{~cm}$ in boys and $31,5 \mathrm{~cm}$ in girls, or less than two SD, considering sex and gestational age, using WHO graphs for term infants and Fenton graphs for preterm infants ${ }^{8}$. After the Ministry of Health reviewed the criteria, microcephaly was redefined as CP lower than two SD in relation to the mean for gestational age and gender ${ }^{8}$, using the InterGrowth spreadsheets for premature NBs and WHO tables for full-term, normal delivery NBs, corrected for sex and gestational age ${ }^{9}$. Data on birth, CP, weight, gestational age, clinical and radiological changes, maternal and gestational conditions, and pregnant women's possible exposures were collected from RESP records.

Case evaluation flow: The evaluation of the cases reported to RESP started at the State Health Surveillance Center (CEVS), which centralized the information of the reported cases sent by health services from each municipality. A multidisciplinary team of geneticists, pediatricians, neurologists and nurses evaluated all RESP records and Rio Grande do Sul Central Laboratory (LACEN) results. Patient care and evaluation were initially performed in the city of origin and, if the local facility did not provide the necessary professionals and tests for the investigation, patients were then referred to Hospital de Clínicas in Porto Alegre, capital of Rio Grande do Sul. For these patients, additional tests were performed, including imaging and other specific tests as indicated for each case. The NB investigation at Hospital de Clínicas included clinical evaluation, information on gestation, and brain imaging for diagnosis or exclusion of infectious disease.

Diagnostic criteria and laboratory analyses: In order to establish the diagnosis of congenital infection, NB's clinical manifestations as well as NB's and mother's test results were considered. Simultaneously to the notification, blood samples from the mother and NB were sent to LACEN, where serologies (direct chemiluminescence) were performed for toxoplasmosis and rubella, and polymerase chain reaction (PCR) was performed for ZIKV in the blood. Venereal Disease Research Laboratory (VDRL) test in the blood for syphilis and PCR in the urine or cerebrospinal fluid (CSF) for CMV were collected in the laboratory. Tests for herpes virus could not be carried out because they are currently unavailable in the public health system.

Brain imaging tests consisted of ultrasonography (US), computed tomography (CT) or magnetic resonance imaging (MRI), in order to evaluate anomalies in the CNS in the NBs.

For diagnostic specificity, the following criteria were used: 1) congenital ZIKV infection confirmed through the mother's travel history to epidemic/ endemic regions in 2015 (see below), skin rash with or without pruritus, joint pain and fever, typical CNS imaging and clinical examination of the NB, or PCR test for ZIKV in the mother's and the NB's blood ${ }^{10} ; 2$ ) congenital CMV infection confirmed by positive PCR in the urine; 3 ) toxoplasmosis and rubella confirmed by serology with positive immunoglobulin (IgM) in the blood; 4) congenital syphilis confirmed by the VDRL test in the NB's blood and/or CSF or positive fluorescent treponemal antibody absorption (FTAABS) test in the NB.

Definition of epidemic/endemic region: For NBs whose mothers were pregnant in 2015, history of travel or residence was checked as well as any available information on detection of autochthonous or imported cases of ZIKV infection. As of 2016, ZIKV was known to circulate in Rio Grande do Sul; therefore, history of travel was not considered part of criteria for diagnosis or suspicion ${ }^{10}$.

Statistical analysis: Data analysis was performed using the Statistical Package for Social Sciences (SPPS $\AA$ ), version 20.0. Descriptive data were shown as frequency, while parametric variables were shown as mean \pm standard deviation.

Ethical aspects: The project was submitted to the Human Research Ethics Committee of the Hospital de Clínicas Research and Graduate Studies Group (GPPG/HCPA 169577). It is in compliance with the regulations in force in the scope of research involving 
human beings, in particular National Health Council Resolution no. 466 of 2012 and complementary resolutions, in addition to the rules and regulations of the institution.

\section{RESULTS}

Of the 257 infants with microcephaly reported in this period, 39 were diagnosed with congenital infections.
The general sample description is shown in Table 1. In relation to the diagnosis of congenital infections, three patients $(7.7 \%)$ were diagnosed with ZIKV (Table 2), nine (23.1\%) with congenital CMV (Table 3), nine $(23.1 \%)$ with congenital toxoplasmosis (Table 4 ), and $18(46.1 \%)$ with congenital syphilis (Table 5). No cases of congenital rubella were diagnosed, and mothers showed immunity to this disease in $91.6 \%$ of all cases reported.

Table 1: Characteristics of the mothers and their 39 newborns with microcephaly and/or central nervous system changes diagnosed with congenital infection.

\begin{tabular}{|c|c|c|}
\hline Newborn characteristics $(n=39)$ & $\mathbf{N}$ & $(\%)$ \\
\hline \multicolumn{3}{|l|}{ Sex } \\
\hline Female & 28 & 71.8 \\
\hline Male & 11 & 28.2 \\
\hline \multicolumn{3}{|l|}{ Diagnosis } \\
\hline Zika virus & 3 & 7.7 \\
\hline Cytomegalovirus & 9 & 23.1 \\
\hline Toxoplasmosis & 9 & 23.1 \\
\hline Syphilis & 18 & 46.1 \\
\hline \multicolumn{3}{|l|}{ Weight at birth } \\
\hline Very low weight $(<1,500$ grams) & 5 & 12.8 \\
\hline Low weight $(1,500-2,500$ grams $)$ & 19 & 48.7 \\
\hline Normal weight (> 2,500 grams) & 15 & 38.5 \\
\hline Small for gestational age & 16 & 41.0 \\
\hline Zika virus $(n=3)$ & 2 & 66.7 \\
\hline Cytomegalovirus ( $n=9$ ) & 2 & 22.2 \\
\hline Toxoplasmosis $(n=9)$ & 4 & 44.4 \\
\hline Syphilis $(n=18)$ & 8 & 44.4 \\
\hline Prematurity & 13 & 33.3 \\
\hline Zika virus $(\mathrm{n}=3)$ & 0 & 0 \\
\hline Cytomegalovirus $(n=9)$ & 3 & 33.3 \\
\hline Toxoplasmosis $(n=9)$ & 4 & 44.4 \\
\hline Syphilis $(n=18)$ & 6 & 33.3 \\
\hline Severe microcephaly (CP $<3 \mathrm{SD}$ ) & 13 & 33.3 \\
\hline Zika virus $(n=3)$ & 2 & 66.7 \\
\hline Cytomegalovirus ( $n=9$ ) & 3 & 33.3 \\
\hline Toxoplasmosis $(n=9)$ & 2 & 22.2 \\
\hline Syphilis $(\mathrm{n}=18)$ & 6 & 33.3 \\
\hline Cerebral alterations in imaging tests* & 20 & 51.3 \\
\hline Zika virus $(\mathrm{n}=3)$ & 3 & 100 \\
\hline Cytomegalovirus s $(n=9)$ & 6 & 66.7 \\
\hline Toxoplasmosis $(\mathrm{n}=9)$ & 7 & 77.8 \\
\hline Syphilis $(n=18)$ & 4 & 22.2 \\
\hline
\end{tabular}


Table 1: Continuation

\begin{tabular}{|c|c|c|c|}
\hline & Maternal characteristics & $\mathbf{N}$ & $(\%)$ \\
\hline \multicolumn{4}{|l|}{ Age } \\
\hline$<20$ & & 7 & 17.9 \\
\hline $20-35$ & & 28 & 71.8 \\
\hline$>35$ & & 4 & 10.3 \\
\hline \multicolumn{4}{|c|}{ Color (self-reported) } \\
\hline White & & 29 & 74.4 \\
\hline Brown & & 6 & 15.4 \\
\hline Black & & 4 & 10.2 \\
\hline
\end{tabular}

${ }^{*}$ Brain imaging test was carried out in 31 patients. CP: cephalic perimeter; SD: standard deviation.

Table 2: Description of cases of congenital Zika virus syndrome $(n=3)$.

\begin{tabular}{|c|c|c|c|c|c|c|}
\hline No. & Sex & GA & WB & $\begin{array}{c}\mathrm{CPI} \\
\text { Percentile }\end{array}$ & $\begin{array}{c}\text { PCR } \\
\text { Altered }\end{array}$ & Brain Imaging Test \\
\hline 1 & $M$ & 37 & 2,740 & $\begin{aligned} & 31 \\
< & 2 \text { SD }\end{aligned}$ & ND & $\begin{array}{l}\text { CT: Small punctate periventricular calcifications } \\
\text { together with increased dimensions of the } \\
\text { ventricular system with predominance of the } \\
\text { posterior horns (colpocephaly) and irregularity in } \\
\text { the contours. } \\
\text { MRI: Lissencephaly and polymicrogyria. } \\
\text { Pachygyria. Reduction of supratentorial white } \\
\text { matter. Craniofacial disproportion. }\end{array}$ \\
\hline 2 & $\mathrm{~F}$ & 38 & 2,436 & $\begin{aligned} & 27 \\
< & 3 \mathrm{SD}\end{aligned}$ & ND & $\begin{array}{l}\text { MRI: Brain atrophy. Lissencephaly, pachygyria, } \\
\text { microcalcifications. }\end{array}$ \\
\hline 3 & $\mathrm{~F}$ & 37 & 2,100 & $\begin{array}{c}26.5 \\
<3 \mathrm{SD}\end{array}$ & ND & $\begin{array}{l}\text { MRI: Craniofacial disproportion. Brain atrophy, } \\
\text { lissencephaly, calcifications. }\end{array}$ \\
\hline
\end{tabular}

No: number of identification; WB: weight at birth in grams; GA: gestational age in weeks; CP: cephalic perimeter in centimeters; SD: standard deviation; PCR: polymerase chain reaction; ND: non-detectable; CT: computed tomography; US: ultrasonography; MRI: magnetic resonance imaging.

Table 3: Description of cases of congenital cytomegalovirus syndrome $(n=9)$.

\begin{tabular}{|c|c|c|c|c|c|c|}
\hline No. & Sex & GA & WB & $\begin{array}{c}\text { CPI } \\
\text { Percentile }\end{array}$ & $\begin{array}{c}\text { PCR } \\
\text { Altered }\end{array}$ & Brain Imaging Test \\
\hline 4 & $\mathrm{~F}$ & 38 & 2,490 & $\begin{aligned} & 30 \\
&< 3 \mathrm{SD} \\
&\end{aligned}$ & $\begin{array}{l}\text { Urine } \\
\text { CSF }\end{array}$ & $\begin{array}{l}\text { US: Cystic images in bilateral subependymal situation. } \\
\text { CT with no alterations. }\end{array}$ \\
\hline 5 & $\mathrm{~F}$ & 35 & 2,320 & $\begin{aligned} & 30 \\
< & 2 \mathrm{SD}\end{aligned}$ & Urine & $\begin{array}{l}\text { US: Areas of periventricular calcification, reduced } \\
\text { volumes in the frontal and parietal gyri. Corpus } \\
\text { callosum formed, but thin. } \\
\text { CT: Small bilateral periventricular calcifications. } \\
\text { MRI: Periventricular calcifications. }\end{array}$ \\
\hline 6 & M & 37 & 2,685 & $\begin{aligned} & 31 \\
&< 2 \mathrm{SD} \\
&\end{aligned}$ & Urine & CT with no alterations. \\
\hline 7 & M & 37 & 2,510 & $\begin{aligned} & 29 \\
< & 3 \mathrm{SD}\end{aligned}$ & Urine & $\begin{array}{c}\text { MRI: Overall increase in CSF spaces by encephalic } \\
\text { volume reduction. Cortical gyri and sulci simplification, } \\
\text { with areas of cortical thickening related to a neuronal } \\
\text { migration disorder with a predominant pattern of } \\
\text { polymicrogyria. } \\
\text { Periventricular calcifications. Alteration in cerebellum } \\
\text { morphology. }\end{array}$ \\
\hline 8 & $\mathrm{~F}$ & 38 & 2,666 & $\begin{aligned} & 31 \\
&< 2 \mathrm{SD} \\
&\end{aligned}$ & Urine & CT with no alterations. \\
\hline
\end{tabular}


Herber et al.

Table 3: Continuation

\begin{tabular}{ccccccc}
\hline No. & Sex & GA & WB & $\begin{array}{c}\text { CPI } \\
\text { Percentile }\end{array}$ & $\begin{array}{c}\text { PCR } \\
\text { Altered }\end{array}$ & Brain Imaging Test \\
\hline 9 & $\mathrm{M}$ & 40 & 2,255 & $\begin{array}{c}28.5 \\
<3 \mathrm{SD}\end{array}$ & Urine & $\begin{array}{c}\text { CT: Signs of reduced cranial volume. Bilateral front } \\
\text { parietal parenchymal calcifications of less than } 6 \text { mm. } \\
\text { Lateral ventricles grossly parallel, which might be } \\
\text { related to colpocephaly. }\end{array}$ \\
\hline 10 & $\mathrm{~F}$ & 39 & 3,355 & $\begin{array}{c}34.5 \\
\text { Adequate }\end{array}$ & Urine & $\begin{array}{c}\text { MRI: Craniofacial disproportion. Enlargement of } \\
\text { lateral ventricles and third ventricle. Corpus callosum } \\
\text { splenium not identified, callosal dysgenesis. } \\
\text { Prominence of CSF spaces in frontal regions. }\end{array}$ \\
\hline 11 & $\mathrm{M}$ & 35 & 2,362 & $\begin{array}{c}29 \\
<2 \text { SD }\end{array}$ & Urine & $\begin{array}{c}\text { US: Ventricular dilation. Supratentorial hydrocephalus. } \\
\text { Reduced parenchymal thickness. Multiple calcified foci. }\end{array}$ \\
\hline 12 & $\mathrm{M}$ & 36 & 2,795 & $\begin{array}{c}30.5 \\
<1 \mathrm{SD}\end{array}$ & Urine & Imaging test not performed. \\
\hline
\end{tabular}

No: number of identification; WB: weight at birth in grams; GA: gestational age in weeks; CP: cephalic perimeter in centimeters; SD: standard deviation; PCR: polymerase chain reaction; CSF: cerebrospinal fluid; CT: computed tomography; MRI: magnetic resonance imaging; US: ultrasonography.

Table 4: Description of cases of congenital toxoplasmosis $(n=9)$.

\begin{tabular}{|c|c|c|c|c|c|c|c|}
\hline No. & Sex & GA & WB & $\begin{array}{c}\text { CPI } \\
\text { Percentile }\end{array}$ & $\lg M$ & $\begin{array}{l}\text { Ophthalmologic } \\
\text { Alteration }\end{array}$ & Brain Imaging Test \\
\hline 13 & $\mathrm{~F}$ & 37 & 2,405 & $\begin{aligned} & 31.5 \\
< & 2 \mathrm{SD}\end{aligned}$ & CSF & Normal fundus & $\begin{array}{l}\text { US: Tiny hypo/anechoic image in the } \\
\text { choroid plexus of left lateral ventricle } \\
\text { (small cyst). }\end{array}$ \\
\hline 14 & $\mathrm{~F}$ & 35 & 1,925 & $\begin{aligned} & 29 \\
< & 2 \mathrm{SD}\end{aligned}$ & Blood & $\begin{array}{l}\text { Microcornea } \\
\text { Microphthalmia } \\
\text { Retinal detachment }\end{array}$ & $\begin{array}{c}\text { US: Calcifications, cysts, parenchymal } \\
\text { reduction, accentuated hydrocephalus, } \\
\text { leukoencephalomalacia. } \\
\text { CT: Hydrocephalus, calcifications. }\end{array}$ \\
\hline 15 & $\mathrm{~F}$ & 38 & 2,668 & $\begin{aligned} & 31 \\
< & 2 \mathrm{SD}\end{aligned}$ & Blood & Normal fundus & CT with no alterations. \\
\hline 16 & $\mathrm{~F}$ & 39 & 2,830 & $\begin{aligned} & 31.5 \\
< & 2 \mathrm{SD}\end{aligned}$ & Blood & NP & CT with no alterations. \\
\hline 17 & M & 38 & 2,625 & $\begin{aligned} & 30 \\
< & 3 \mathrm{SD}\end{aligned}$ & $\begin{array}{l}\text { Blood/ } \\
\text { CSF }\end{array}$ & NP & $\begin{array}{l}\text { CT: Diffuse cortical sulci prominence. } \\
\text { Apparent callosal dysgenesis. } \\
\text { Hypoplasia of the cerebellum. }\end{array}$ \\
\hline 18 & $\mathrm{~F}$ & 31 & 1,200 & $\begin{aligned} & 24.5 \\
< & 2 \mathrm{SD}\end{aligned}$ & $\begin{array}{l}\text { Blood/ } \\
\text { CSF }\end{array}$ & $\begin{array}{l}\text { Posterior uveitis with } \\
\text { macular involvement } \\
\text { and vitreitis }\end{array}$ & $\begin{array}{l}\text { CT: Gross calcifications predominantly } \\
\text { bilateral and symmetrical cortical } \\
\text { and next to walls of lateral ventricles. } \\
\text { Ventricular system dilation, } \\
\text { colpocephaly. }\end{array}$ \\
\hline 19 & $\mathrm{~F}$ & 38 & 2,570 & $\begin{array}{l}30.5 \\
<2 \mathrm{SD}\end{array}$ & CSF & Normal fundus & $\begin{array}{l}\text { CT: Small subdural collection next to } \\
\text { territory and occipital region. Small right } \\
\text { parietal brain hematoma. }\end{array}$ \\
\hline 20 & $\mathrm{~F}$ & & 1,070 & $\begin{aligned} & 24 \\
< & 3 \mathrm{SD}\end{aligned}$ & Blood & NP & $\begin{array}{l}\text { US: Minimum increase in echogenicity } \\
\text { of periventricular white matter. } \\
\text { CT: Signs of reduced cranial volume. }\end{array}$ \\
\hline 21 & $\mathrm{~F}$ & & 2,430 & $\begin{aligned} & 30.5 \\
< & 1 \mathrm{SD}\end{aligned}$ & Blood & NP & $\begin{array}{l}\text { US: Small calcifications. } \\
\text { Encephalomalacia. Ventriculomegaly. }\end{array}$ \\
\hline
\end{tabular}

No: number of identification; WB: weight at birth in grams; GA: gestational age in weeks; CP: cephalic perimeter in centimeters; SD: standard deviation ; IgM: immunoglobulin M ; CSF: cerebrospinal fluid; CT: computed tomography; US: ultrasonography; NP: not performed. 
Table 5: Description of cases of congenital syphilis $(n=18)$.

\begin{tabular}{|c|c|c|c|c|c|c|c|}
\hline No. & Sex & GA & WB & $\begin{array}{c}\text { CPI } \\
\text { Percentile }\end{array}$ & $\begin{array}{l}\text { VDRL } \\
\text { Mother }\end{array}$ & $\begin{array}{l}\text { VDRL } \\
\text { NB }\end{array}$ & Brain Imaging Test \\
\hline 22 & M & 33 & 1,455 & $\begin{aligned} & 27.2 \\
< & 2 \mathrm{SD}\end{aligned}$ & $1: 256$ & $1: 64$ & US: Grade 1 hemorrhage. \\
\hline 23 & $\mathrm{~F}$ & 38 & 2,310 & $\begin{aligned} & 30 \\
< & 3 \mathrm{SD}\end{aligned}$ & $1: 8$ & $1: 2$ & NA \\
\hline 24 & $\mathrm{~F}$ & 38 & 3,160 & $\begin{aligned} & 31 \\
< & 2 \mathrm{SD}\end{aligned}$ & $1: 8$ & FTA-ABS R & US with no alterations. \\
\hline 25 & $\mathrm{~F}$ & 38 & 2,500 & $\begin{aligned} & 30.5 \\
< & 2 \mathrm{SD}\end{aligned}$ & $1: 4$ & $\begin{array}{c}1: 1 \\
\text { FTA-ABS R }\end{array}$ & NA \\
\hline 26 & $\mathrm{~F}$ & 37 & 2,535 & $\begin{aligned} & 30 \\
< & 3 \mathrm{SD}\end{aligned}$ & $1: 8$ & $\mathrm{R}^{*}$ & NA \\
\hline 27 & $\mathrm{~F}$ & 37 & 2,740 & $\begin{aligned} & 31.5 \\
< & 2 \mathrm{SD}\end{aligned}$ & $1: 1$ & $\mathrm{R}^{*}$ & CT with no alterations. \\
\hline 28 & $\mathrm{~F}$ & 37 & 1,725 & $\begin{aligned} & 30 \\
< & 3 \mathrm{SD}\end{aligned}$ & $1: 4$ & $1: 1$ & US with no alterations. \\
\hline 29 & $\mathrm{~F}$ & 32 & 1,120 & $\begin{aligned} & 26 \\
< & 2 \mathrm{SD}\end{aligned}$ & $1: 2$ & $\mathrm{R}^{*}$ & $\begin{array}{l}\text { US: Mineralizing vasculopathy in } \\
\text { thalamus. Ventricles of normal } \\
\text { dimensions and aspects. }\end{array}$ \\
\hline 30 & $\mathrm{~F}$ & 35 & 1,535 & $\begin{aligned} & 27 \\
&< 3 \mathrm{SD} \\
&\end{aligned}$ & $1: 64$ & $1: 8$ & US with no alterations. \\
\hline 31 & M & 37 & 1,785 & $\begin{aligned} & 30 \\
< & 3 \mathrm{SD}\end{aligned}$ & $1: 8$ & $1: 1$ & $\begin{array}{c}\text { US: Suggestive of congenital infections. } \\
\text { Cystic images in the caudothalamic } \\
\text { groove. }\end{array}$ \\
\hline 32 & $\mathrm{~F}$ & 38 & 2,775 & $\begin{aligned} & 31.5 \\
< & 2 \text { SD }\end{aligned}$ & $1: 4$ & $1: 4$ & NA \\
\hline 33 & $\mathrm{~F}$ & 35 & 2,015 & $\begin{aligned} & 30 \\
< & 1 \mathrm{SD}\end{aligned}$ & $1: 1024$ & FTA-ABS R & US with no alterations. \\
\hline 34 & $\mathrm{~F}$ & 41 & 3,105 & $\begin{aligned} & 31 \\
< & 2 \mathrm{SD}\end{aligned}$ & $1: 2$ & FTA-ABS R & US with no alterations. \\
\hline 35 & $F$ & 36 & 1,995 & $\begin{aligned} & 29 \\
< & 2 \mathrm{SD}\end{aligned}$ & $1: 64$ & $1: 16$ & US with no alterations. \\
\hline 36 & $\mathrm{~F}$ & 37 & 2,195 & $\begin{aligned} & 30.5 \\
< & 1 \mathrm{SD}\end{aligned}$ & $1: 32$ & $1: 16$ & NA \\
\hline 37 & $\mathrm{~F}$ & 31 & 1,125 & $\begin{aligned} & 25 \\
< & 2 \mathrm{SD}\end{aligned}$ & $1: 64$ & $1: 16$ & NA \\
\hline 38 & M & 38 & 2,040 & $\begin{aligned} & 31 \\
< & 2 \mathrm{SD}\end{aligned}$ & $1: 16$ & $1: 4$ & NA \\
\hline 39 & M & 38 & 2,085 & $\begin{aligned} & 29.5 \\
< & 3 \mathrm{SD}\end{aligned}$ & $1: 32$ & $1: 16$ & $\begin{array}{l}\text { US: Suggestive of congenital infections. } \\
\text { Vasculopathy of thalamus. }\end{array}$ \\
\hline
\end{tabular}

No: number of identification; WB: weight at birth in grams; GA: gestational age in weeks; CP: cephalic perimeter in centimeters; R: reagent (but with no titration values available); SD: standard deviation; NA: not available; CT: computed tomography; US: ultrasonography; VDRL: Venereal Disease Research Laboratory; FTA-ABS: fluorescent treponemal antibody absorption test.

\section{ZIKV embryopathy}

Patient 1 - the mother presented with red spots and reported having traveled to southeast Brazil (where ZIKV was circulating) about ten days before symptom onset, at the end of the first gestational trimester. The NB exhibited developmental dysplasia, bilateral feet malposition, and strabismus.
Patient 2 - the mother presented with red spots, fever, myalgia, arthralgia and retro-orbital pain at the end of the first gestational trimester, about ten days after traveling to northeast Brazil, where the virus was circulating.

Patient 3 - the mother reported not having traveled during pregnancy but showed typical symptoms of 
ZIKV infection, such as exanthema, arthralgia and myalgia, in the second gestational trimester. This NB presented overriding sutures, increased prominence of supraorbital ridge, retrognathia, delayed tooth eruption, arthrogryposis, motor hypoactivity, hypertonia, cortical thumb and neuropsychomotor development delay (NPMD).

All mothers and their NBs had negative PCR for ZIKV in the postnatal period. This test was not available at the time of clinical symptoms in the pregnant women. All NBs demonstrated phenotypic findings compatible with ZIKV embryopathy, including arthrogryposis, increased skin fold in the occipital region, and alterations in neurological examination (irritability, excessive crying, hypertonia, excessive thumb adduction, hyperactive myotatic reflexes).

\section{Congenital CMV}

Among the nine patients diagnosed with congenital CMV, five presented with severe microcephaly. Of eight NBs who underwent imaging tests, six presented with cerebral anomalies compatible with congenital infections. Three NBs underwent ophthalmologic evaluation; NB 5 presented with nonspecific alterations in the retina and NB 6 presented with microphthalmia.

\section{Congenital toxoplasmosis}

Among the nine NBs diagnosed with congenital toxoplasmosis, two presented with severe microcephaly. All nine NBs underwent imaging tests, and seven had alterations. NBs 14,18 and 21 presented with brain calcifications and NB 14 also presented with hydrocephalus. Five NBs underwent ophthalmologic evaluation, and three presented with severe changes compatible with toxoplasmosis.

\section{Congenital syphilis}

Among the eleven NBs who underwent imaging tests, four had cerebral alterations. The maternal VDRL titration ranged from $1: 4$ to $1: 250$, while the NB VDRL titration ranged from 1:1 to 1:64. The VDRL in the CSF was collected from eight NBs, two of which were altered. Six NBs underwent long bone x-ray, all without alterations.

\section{DISCUSSION}

As the ZIKV epidemic began in Brazil at the end of 2015, the Brazilian Ministry of Health adopted the compulsory surveillance of microcephaly cases and CNS alterations in order to establish causality between such alterations and ZIKV infection ${ }^{6}$. This made it possible to know not only the prevalence at birth of a previously neglected condition but also other causes of microcephaly due to infections occurring earlier than 2015 in the state of Rio Grande do Sul and the rest of Brazil. These infections already had their profile of gestational outcomes known; however, the impact they had on the population was unknown. In Brazil, the Ministry of Health includes prenatal testing and treatments for toxoplasmosis and syphilis ${ }^{11}$. In the past decade, the Ministry of Health improved the assistance of pregnant women through protocols, thus reducing perinatal and neonatal morbidity and mortality. A great example is the eradication of congenital rubella in 2010 through vaccination in women of childbearing age, confirmed by the fact that no NBs were diagnosed with such infection. Moreover, the mothers of the reported NBs showed $91.6 \%$ of acquired immunity to rubella, which is consistent with the worldwide goal of rubella infection eradication achieved by Brazil's vaccination program ${ }^{12}$.

In this study, $48.7 \%$ of the NBs were small for gestational age and $33.3 \%$ were preterm. Such characteristics are commonly found in congenital infections due to the activation of the inflammatory response in these babies ${ }^{1}$. Similar data of low weight and prematurity were related to patients with microcephaly ${ }^{13,14}$. In addition, low birth weight and prematurity are factors that increase the risk of perinatal mortality and future sequelae, as damage to the fetus is irreversible. Early diagnosis and treatment for pregnant women and NBs can minimize sequelae, especially in cases of toxoplasmosis and syphilis ${ }^{2}$.

An important finding in the sample evaluated was the fact that $33.3 \%$ of the NBs had severe microcephaly and $51.3 \%$ presented with alterations in the imaging tests, indicating a high rate of severe neurological abnormalities and reinforcing the knowledge of how important these infections can be when compromising the NB. In this study, three cases of ZIKV were identified, which corresponds to a very small number when compared to the rest of Brazil. The distribution of infection by the virus in Brazil was mostly $(70.4 \%)$ in the Northeast region, whereas the South region was less affected due to local climate ${ }^{6}$. Rio Grande do Sul is the southernmost state in Brazil and, in winter, average temperatures range from $15^{\circ} \mathrm{C}$ to $18^{\circ} \mathrm{C}$. In April 2016, when the number of cases began to increase, temperature was already declining, which did not favor the spread of the disease by its main vector, the Aedes aegypti mosquito ${ }^{8}$.

The clinical presentation of ZIKV embryopathy cases, including arthrogryposis, increased skin fold in the occipital region, alterations in neurological and imaging tests compatible with the classic clinical picture of ZIKV infection (brain calcification and delayed brain development) as described in the literature, was crucial for diagnosis ${ }^{15,16}$.

Cases of microcephaly associated with ZIKV accounted for $5 \%$ of all cases of microcephaly evaluated between 2015 and 2017. In 2016, there were three confirmed cases. In 2017, there were 
one confirmed case and five probable cases. The study was performed during the period of highest prevalence of ZIKV infection in Brazil. In recent years, cases dropped significantly ${ }^{17}$.

The CMV cases had important alterations in the brain imaging tests as well as several cases of severe microcephaly, in contrast to the existing literature, which reports only $20 \%$ to $30 \%$ of patients with severe symptoms and brain alterations ${ }^{18}$. Although congenital infection is more frequent due to high seropositivity rates in developing countries, about $90 \%$ of the infected are born asymptomatic and, of these, $5 \%$ to $15 \%$ may develop neurological and sensorineural symptoms in the first months or years of life. Among those who are symptomatic at birth, the percentage of sequelae is much higher (greater than $50 \%$ to $80 \%)^{19}$. Early diagnosis of congenital CMV infection and clinical follow-up are essential for detecting and handling the disease, especially to prevent sequelae. Despite the importance of this infection, many infants congenitally infected with CMV remain unidentified because screening is not routinely carried out in prenatal care and more than $90 \%$ of the affected babies are asymptomatic at birth ${ }^{11}$.

Among the NBs with congenital toxoplasmosis, only one case of hydrocephalus, three cases of chorioretinitis, and three cases of brain calcification were identified. Similar results were found in a previous study with a similar population, which identified microcephaly in $20.8 \%$, intracranial calcification in $37.5 \%$ and chorioretinitis in $54 \%$ of the sample ${ }^{20}$. Screening for toxoplasmosis during pregnancy can anticipate the diagnosis so that treatment is performed at gestation, reducing the risk of injury to the $\mathrm{NB}^{11,21}$.

Syphilis was the most frequent congenital infection in the study (46.1\%), as expected. The rate of transmission from the pregnant woman to the fetus was $70 \%$ to $100 \%$ depending on the stage of the disease, significantly higher than other infections ${ }^{2}$. Despite the Ministry of Health's efforts to reduce syphilis, this disease is still associated with other risk factors, such as human immunodeficiency virus (HIV) infection and drug use ${ }^{22}$. The difficulties in reducing the incidence and transmission of this disease may be partially explained by a generally asymptomatic condition and inadequate treatment of the pregnant woman and the partner ${ }^{11,23}$. In addition, the 2016 Epidemiological Bulletin of the Ministry of Health warned of the growing number of cases of syphilis in the country in recent years, especially in the South region, emphasizing that Porto Alegre has a congenital syphilis rate four times higher than the national average. This increase in recent years is consistent with our findings of a large number of cases of congenital syphilis and microcephaly ${ }^{24}$.
This study has some limitations associated with the use of retrospective data susceptible to information bias. In addition, the gestational period in which most infections occurred could not be established, to compare with the clinical findings of the NB. The study was developed during a period of modification of Ministry of Health guidelines regarding the diagnostic criteria of microcephaly, and health professionals needed to identify a disease that was not well known yet. Since the availability of the tests needed to be absorbed by health services, brain imaging tests such as MRI became costly and more difficult to access. However, in this study, US and CT tests showed specific alterations of infectious diseases with adequate precision.

After the onset of mandatory reporting of NBs with microcephaly and/or other CNS changes, it was possible to describe these conditions and their association with microcephaly and other neurological changes. Actions that already exist can be improved, particularly for preventable causes. Prevention of ZIKV infection has been the focus of efforts taken by the Ministry of Health, including vector control and guidelines for women who wish to become pregnant.

This study shows the importance of mandatory reporting as a measure to identify the frequency that microcephaly is caused by congenital infections, including ZIKV. Infection with this virus was infrequent in the study, which was expected due to the low circulation of the virus in our state. Most cases of congenital infections include severe neurological lesions, especially the cases of ZIKV infection, which is known to cause neurological development delays and sequelae to infants during early childhood. Thus, this study can serve as a basis for public health policies on how to handle these infections in pregnancy and on the care and health needs of the NB.

\section{Funding}

This work was funded by the Research Incentive Fund at Hospital de Clínicas de Porto Alegre (FIPE-HCPA 160577) and the National Council for Scientific and Technological Development (CNPq).

\section{Conflict of interests}

The authors state that there is no conflict of interest.

\section{Acknowledgements}

We thank the State Health Surveillance Center (CEVS) for support in case analysis; the Teratogen Information Service (SIAT) for support in the investigation of data; the Hospital de Clínicas de Porto Alegre (HCPA) hospital administration for having been the hospital reference; and the Graduate Program in Medical Sciences at Federal University of Rio Grande do Sul. 


\section{REFERENCES}

1. Ashwal S, Michelson D, Plawner L, Dobyns WB. Practice parameter: evaluation of the child with microcephaly (an evidence-based review): report of the Quality Standards Subcommittee of the American Academy of Neurology and the Practice Committee of the Child Neurology Society. Neurology. 2009;73(11):887-97.

2. Silasi M, Cardenas I, Kwon JY, Racicot K, Aldo P, Mor G. Viral infections during pregnancy. $\mathrm{Am} \mathrm{J}$ Reprod Immunol. 2015;73(3):199-213.

3. World Health Organization (WHO), National Center on Birth Defects and Developmental Disabilities from the United States Centers for Disease Control and Prevention (CDC), International Clearinghouse for Birth Defects Surveillance and Research (ICBDSR). Birth defects surveillance: a manual for programme managers. Genebra: World Health Organization; 2014.

4. Von der Hagen M, Pivarcsi M, Liebe J, von Bernuth $\mathrm{H}$, Didonato $\mathrm{N}$, Hennermann JB, et al. Diagnostic approach to microcephaly in childhood: a two-center study and review of the literature. Dev Med Child Neurol. 2014;56(8):732-41.

5. Del Campo M, Feitosa IM, Ribeiro EM, Horovitz DD, Pessoa AL, França $\mathrm{GV}$, et al. The phenotypic spectrum of congenital Zika syndrome. Am J Med Genet A. 2017;173(4):841-57.

6. Oliveira WK, França GVA, Carmo EH, Duncan BB, Souza Kuchenbecker R, Schmidt MI. Infection-related microcephaly after the 2015 and 2016 Zika virus outbreaks in Brazil: a surveillance-based analysis. Lancet. 2017;390(10097):861-70.

7. Brasil. Ministério da Saúde. Secretaria de Atenção à Saúde. Protocolo de atenção à saúde e resposta à ocorrência de microcefalia relacionada à infecção pelo vírus Zika. Brasília: Ministério da Saúde; 2015.

8. Brasil. Ministério da Saúde. Secretaria de Vigilância em Saúde. Departamento de Vigilância das Doenças Transmissíveis. Protocolo de vigilância e resposta à ocorrência de microcefalia e/ou alterações do sistema nervoso central (SNC). Brasília: Ministério da Saúde; 2016.
9. Villar J, Cheikh Ismail L, Victora CG, Ohuma EO, Bertino E, Altman DG, et al. International standards for newborn weight, length, and head circumference by gestational age and sex: the Newborn Cross-Sectional Study of the INTERGROWTH-21st. Project. Lancet. 2014;384(9946):857-68.

10. Brasil. Ministério da Saúde. Secretaria de Vigilância em Saúde. Secretaria de Atenção à Saúde. Orientações integradas de vigilância e atenção à saúde no âmbito da Emergência de Saúde Pública de Importância Nacional: procedimentos para o monitoramento das alterações no crescimento e desenvolvimento a partir da gestação até a primeira infância, relacionadas à infecção pelo vírus Zika e outras etiologias infeciosas dentro da capacidade operacional do SUS. Brasília: Ministério da Saúde, 2017.

11. Brasil. Ministério da Saúde. Secretaria de Atenção à Saúde. Departamento de Atenção Básica. Atenção ao pré-natal de baixo risco. Brasília: Editora do Ministério da Saúde; 2012. (Série A. Normas e Manuais Técnicos) (Cadernos de Atenção Básica, $n^{\circ} 32$ ).

12. Brasil. Ministério da Saúde. Departamento de Vigilância das Doenças Transmissíveis. Relatório da verificação dos critérios de eliminação da transmissão dos vírus endêmicos do sarampo e rubéola e da síndrome da rubéola congênita (SRC) no Brasil. Brasília: Ministério da Saúde; 2010.

13. Graham KA, Fox DJ, Talati A, Pantea C, Brady L, Carter SL, et al. Prevalence and clinical attributes of congenital microcephaly - New York, 2013-2015. MMWR Morb Mortal Wkly Rep. 2017;66(5):125-9.

14. Cragan JD, Isenburg JL, Parker SE, Alverson CJ, Meyer RE, Stallings EB, et al. Population-based microcephaly surveillance in the United States, 2009 to 2013: an analysis of potential sources of variation. Birth Defects Res A Clin Mol Teratol. 2016;106(11):972-82.

15. Schuler-Faccini L, Sanseverino M, Vianna F, da Silva AA, Larrandaburu $\mathrm{M}$, Marcolongo-Pereira $\mathrm{C}$, Abeche AM. Zika virus: A new human teratogen? Implications for women of reproductive age. Clin Pharmacol Ther. 2016;100(1):28-30.
16. Rasmussen $S A$, Jamieson DJ, Honein MA, Petersen LR. Zika virus and birth defects - reviewing the evidence for causality. $N$ Engl J Med. 2016;374(20):1981-7.

17. Brasil. Ministério da Saúde. Secretaria de Vigilância em Saúde. Monitoramento integrado de alterações no crescimento e desenvolvimento relacionadas à infecção pelo vírus Zika e outras etiologias infecciosas, até a Semana Epidemiológica 52 de 2018. Boletim Epidemiológico. 2019;50(8):1-8.

18. Çelikel E, Tezer H, Kanik-Yuksek S, Gülhan B, Ozkaya-Parlakay A, Yarali N. Evaluation of 98 immunocompetent children with cytomegalovirus infection: importance of neurodevelopmental follow-up. Eur J Pediatr. 2015;174(8):1101-7.

19. Marin LJ, Cardoso ESC, Sousa SMB, Carvalho LD, Marques Filho MF, Raiol MR, Gadelha SR. Prevalence and clinical aspects of CMV congenital infection in a low-income population. Virol J. 2016;13(1):148.

20. Bischoff AR, Friedrich L, Cattan JM, Uberti FA. Incidence of symptomatic congenital toxoplasmosis during ten years in a Brazilian hospital. Pediatr Infect Dis J. 2016;35(12):1313-6.

21. Soares JAS, Násser LS, Carvalho SFG, Caldeira AP. Achados oculares em crianças com toxoplasmose congênita. Arq Bras Oftalmol. 2011;74(4):255-7.

22. Maia MMM, Lage EM, Moreira BCB, Deus EAB, Faria JG, Pinto JA, Melo VH. Prevalência de infecções congênitas e perinatais em gestantes HIV positivas da região metropolitana de Belo Horizonte. Rev Bras Ginecol Obstet. 2015;37(9):421-7.

23. Tiago ZDS, Picoli RP, Graeff SV, Cunha RVD, Arantes R. Underreporting of gestational, congenital and acquired syphilis among indigenous peoples in Mato Grosso do Sul State, Brazil, 2011-2014. Epidemiol Serv Saude. 2017;26(3):503-12.

24. Brasil. Ministério da Saúde. Secretaria de Vigilância em Saúde. Sífilis: 2018. Boletim Epidemiológico. 2018;49(45):3-43. 